\title{
Experimental Research on the Triangular Lattice Type Polymer Based Composites Structures for Sandwich Panels Construction
}

\begin{abstract}
ADRIAN COSTIN DURBACA ${ }^{1}$, RADU IATAN ${ }^{1}$, ION DURBACA* ALIN DINITA2, MARIUS VASILESCU 3
${ }^{1}$ University Politehnica of Bucharest, Faculty of Mechanical Engineering and Mechatronics, 313 Splaiul Independenei, 060042, Bucharest, Romania

2Petroleum Gas University of Ploiesti, Faculty of Mechanical and Electrical Engineering, 39 Bucuresti Blvd., 100520, Ploiesti, Romania

${ }^{3}$ University Politehnica of Bucharest, Faculty of Material Science and Engineering, 313 Splaiul Independenei, 060042, Bucharest, Romania

${ }^{4}$ University Politehnica of Bucharest, Faculty of Biotechnical Systems Engineering, 313 Splaiul Independenei, 060042, Bucharest, Romania

The paper presents experimental results on the mechanical behaviour for a polymer based composite sandwich panel tensile and bending tested, which uses, one by one, a cellular composite core fabricated by additive manufacturing of four different types of polymeric materials: ABS (acrylonitrile butadiene styrene), PC (polycarbonate), PLA (polylactide) and CF (polylactide $+40 \%$ carbon fibre), with the thickness of 3 and $5 \mathrm{~mm}$. This research focuses on comparative analysis of the core thickness increase effecton the structure's strength. Experimental tests carried out on standardized test-pieces with specialized laboratory equipment, are highlighting similar mechanical behaviour and are showing also an increase of composite stiffness with the increase of core thickness, at the same time, the arrangement of the cellular lattice structure has a significant effect on the structural strength.
\end{abstract}

Keywords: composite structure, sandwich panel, cellular composite, additive manufacturing

Development of polymer composites sandwich lightweight and ultra-lightweight structures, used successfully in many industries (aeronautics, aerospace, Naval, railway, automotive etc.), representa rising direction of scientific research. Cellular constructions made of polymer materials, metals and ceramics are now available, although prices are higher compared to standard products. Therefore, they continue to have a continuous introduction on the market, as a result of prosperous developments of manufacturing processes. Such mixes are used in a variety of applications: those from polymer and metal are used for sandwich panels, ranging from cheap doors up to advanced aerospace components; the metal was also used successfully for energy absorption (e.g., landing feet module of Apollo 11 orbiting station were made of aluminium composite sandwich panel with high compression properties) [1], and sandwich composites from ceramic materials have applications in processes involving high temperatures (for example, accelerators and catalytic heat exchangers) [2]. Also, many natural materials (such as wood) can be analysed as idealized honeycomb structures [3].

The word cell derives from the Latin cella, a small compartment or an enclosed space. In the case of groups of cells, which the Romans called cellarium, a less elegant translation is solid cells. After Gibson and Ashby [4], a cellular solid is composed of an interconnected system of solid ties or plates that form the edges and faces of cells.

For the construction of a polymer composite sandwich panel are generally involved three main components (fig. 1): two polymer facings, with the same thickness, a rigid and strong structure, separated by a thick light cellular structure in comparison with outer facings [5-8]. In the literature, the structure of the cell is known as core, due to its location in an assembly comprising the sandwich core in two sheets disposed one on the either side of the cellular core. As part of the sandwich panel, can be considered the addition between core and facings, resulting from joining methods (example: bonding with adhesives in thin film layer and ultra-sticky). This additional ultra-thin layer forces the core and facings to behave as a whole structure, thus transferring axial and transverse loads to and from cellular core.

Cellular core requires enough stiffness to keep a constant distance between the facings. From a structural point of view, the main function of the cellular core in the sandwich structure is to stabilize the facesheets to avoid buckling and deformation and to take the shear loading along its thickness. Facesheets are transferring the tension and compression stresses. Their main function is to offer higher bending stiffness and plane shear to the sandwich structure. The facesheets also carry a part of local stresses.

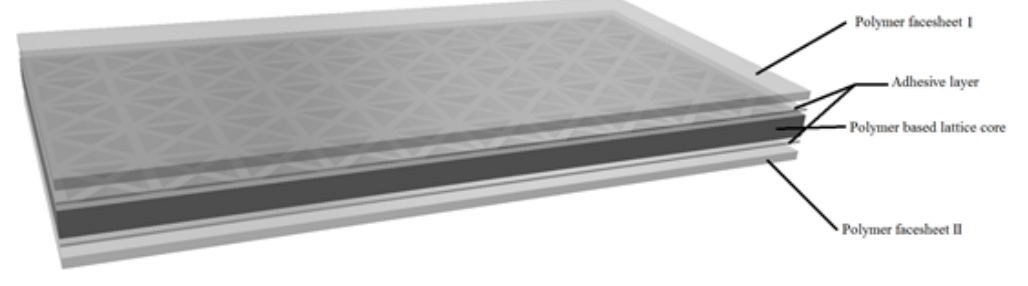

Fig. 1. The layer's structure of a composite sandwich panel $[10,23]$

\footnotetext{
* email: ion.durbaca@yahoo.com.; Phone: 40723277389
} 
In order to maintain the link between the cellular core and the facesheets, thus facilitating the transfer of shear forces, the end result from component joining must withstand mainly shear stresses.

Intense concerns from international academics, demonstrated by the large number of scientific papers published and supported by results obtained in various industrial applications, reflect practicality of polymer composite sandwich panels. However, due to the small degree of automation in manufacturing technologies of cellular cores, on difficulties recorded in the formation of assemblies, as well as higher costs, the use of composite sandwich panels is still limited. In addition, there are industries where, despite the advantages it can offer, sandwich panels are not very much used. The reasons, in addition to the high costand structural integrity, are mainly the manufacture and fitting of panels or the formation of complex architectures and geometries in space. For example, in the context of increased attention granted to environment, land vehicles (road and rail), maritime, or future cosmic, will need to be more efficient in terms of fuel consumption, and therefore lighter, thus forming the use of materials and structures for high performance. An obvious path towards this aim is the extension of the use of sandwich panels with integrated functions. This new concept involves the use of a single sandwich panel for several types of mechanical stresses (static and dynamic), thermal, acoustic, etc. requests, resulting in a constructive solution easier and less expensive, opposite to the use of a separate material for each of the requirements. Also, sandwich panels made in three or more layers, with the inclusion of integrated functions, could represent an efficient technical solution in terms of thermal energy consumption and can be easily accomplished in a short time at a lower cost in comparison to current existing solutions.

\section{Experimental part}

\section{Materials and methods}

The mechanical structure proposed for the study of composite sandwich panels has incorporated the following materials:

- the core cellular polymer made of 4 different types of polymeric materials: ABS (acrylonitrile butadiene styrene), PC (polycarbonate), PLA (polylactide) and CF (carbon fiber), thickness: 3 and $5 \mathrm{~mm}$; cell length ( $): 15 \mathrm{~mm}$, cell wall thickness (t): $2 \mathrm{~mm}$ (fig. 2);
- synthetic glass - Guttagliss Hobyglass (PAD) for polymer facesheets I and II, thickness: $2 \mathrm{~mm}$;

- transparent adhesive for bonding adhesive in a thin ultra-adherent layer - Polymax / crystal express BISON.

These three layers that make up the composite sandwich panel adhere to each other by means of the adhesive, abovementioned.

The triangular lattice type polymer based structures for the cellular polymer core is fabricated by additive manufacturing technology/3D printing (fig. 3) from 4 different types of polymer based materials, abovementioned, with dimensions of $150 \times 150 \times 3 \mathrm{~mm}$, respectively $150 \times 150 \times 5 \mathrm{~mm}$, for test specimen preparation (fig. 4).

The manufacturing of the polymer based structures that will constitute the core of the composite cell was done on a machine type Airwolf 3D HD2DX, using the fused deposition modelling (FDM), through laying down of successive layers of melted plastic.

For tensile testing, respectively bending of the analysed composite materials there were manufactured 2 types of samples per technical standards / rules in place (ASTM C297- tensile test and ASTM C364 - bending test), in determining the mechanical strength characteristics for above mentioned loading.

The specimens shaping after additive manufacturing has been carried out through laser cutting of the 8 types of composite plates, symbolized above (ABS 3.1 / ABS 3.2; ABS 5.1 / ABS 5.2; PC 3.1/ PC 3.2; PC 5.1/ PC 5.2; PLA 3.1 / PLA 3.2; PLA 5.1 / PLA 5.1; CF 3.1 / CF 3.2; CF 5.1 / CF 5.2). The symbolization method of those test specimens was chosen to define the construction material of the cellular polymer based core, the thickness and arrangement of lattice core walls (fig. 5). There have been used, in this case, two different ways of arranging the cell, considering both closed walls and open walls of cellular core (fig. 6).

The experiments were conducted in the laboratories of the Regional centre for determining and monitoring the performance of technical condition of tubular material used in the oil industry of the Faculty of Mechanical and Electrical Engineering at the Petroleum - Gas University of Ploiesti and were based on the completion of a standardized testing program for dog-bone shape type specimens, for tensile testing $(T)$, and rectangular bars specimens for bending testing (B). The purpose of these tests consists in

Fig.2. The orientation and size of cells constituting the core of crosslinking polymer cell
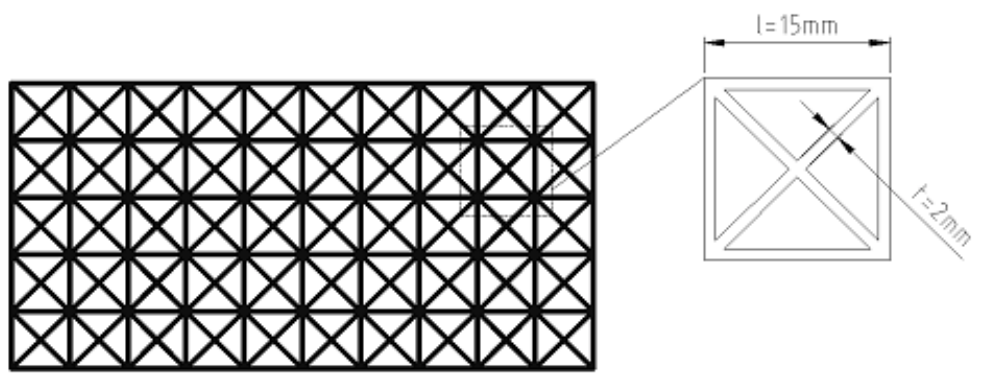

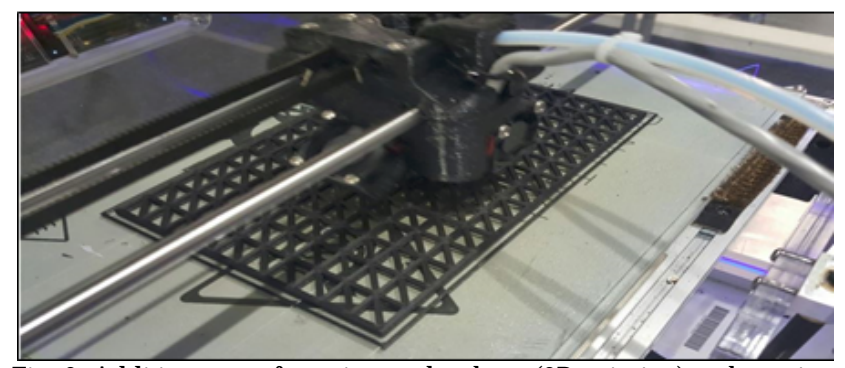

Fig. 3. Additive manufacturing technology (3D printing) polymeric composites structures of cell monolayer type frame.

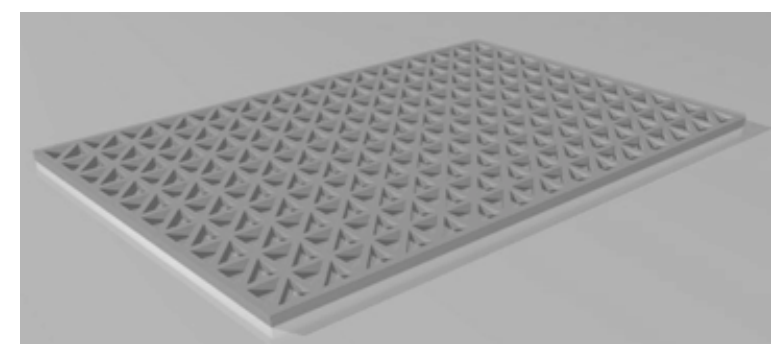

Fig. 4. The 3D geometric model configuration of a structural core, to achieve the cellular polymer based core of the composite panel 

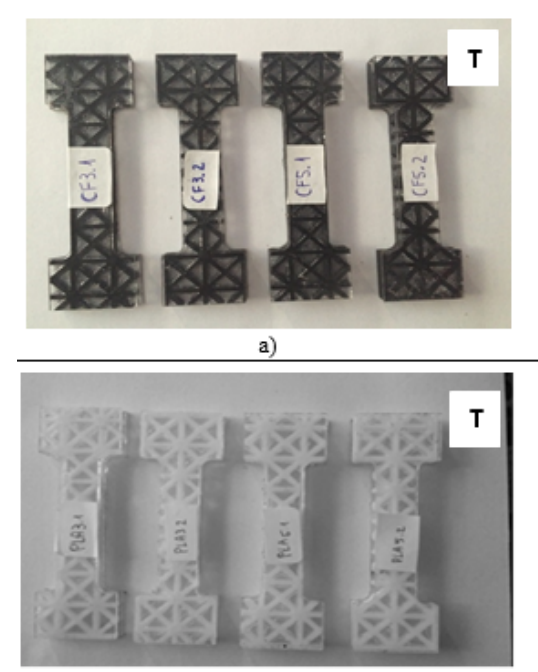

b)

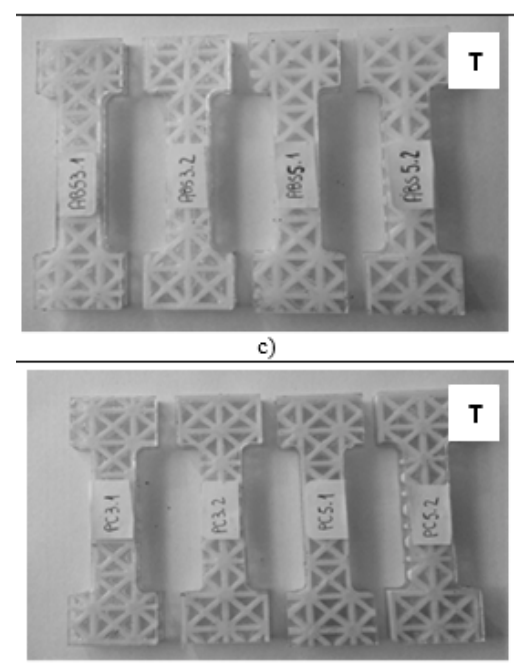

d)

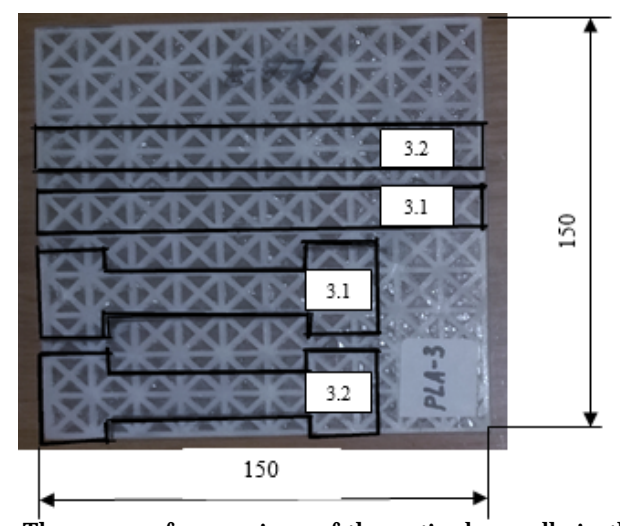

Fig. 6. The ways of arranging of the reticular walls in the cellular core: a) closed walls (,,3.1"); b) open walls (,,3.2")

determining the maximum stress $\sigma$ - strain e, i.e. force $[N]$ - extension $(\mathrm{mm})$ for each type of test sample.

\section{Apparatus used}

To conduct the experiments mentioned above, there were used the following equipment, machines, devices, and specialized programs for testing:

a) testing machine for advanced materials - AMETEK Lloyd Instruments LS 2.5, capacity $2.5 \mathrm{kN}$ (fig. 7a) [5, 22], together with the specific clamping devices of the specimens at tensile testing (fig. $7 \mathrm{~b}$ ).

b) specialized software for connection, data acquisition and processing of test results for testing equipment AMETEK Lloyd Instruments LS 2,5 [22].

c)
Fig. 5. Sizing of tensile test specimens $(T)$ and bending (B): a) - CF3 and CF5; b) - PLA3 and PLA5; C) - ABS3 and ABS5; d) - PC3 and PC5. d)

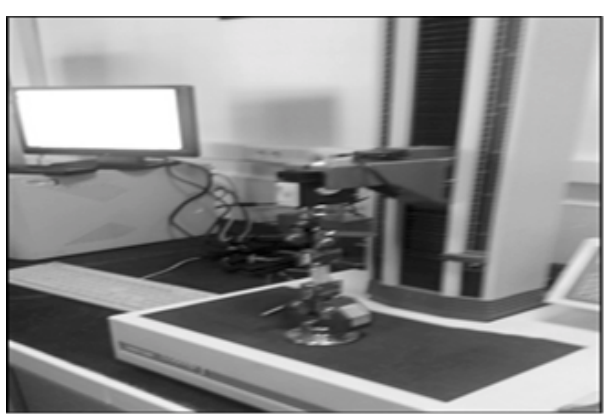

a)

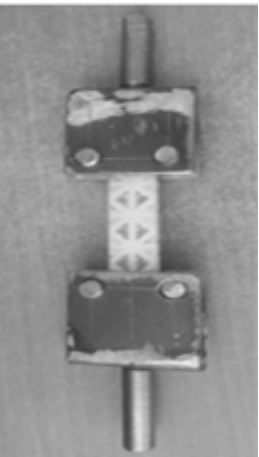

b)
Fig. 7 a- Testing machine for advanced materials - AMETEK Lloyd Instruments LS 2,5 [23]; b- restraining devices for fixing the test specimens at tensile testing.

\section{Results and discussions}

Tensile test results

Tensile tests (T) were performed on standardized testpieces made of composite materials with polymer based cellular core named - PC3.1 / PC3.2, CF3.1 / CF3.2, PLA3.1 / PLA 3.2 and ABS3.1 / ABS3.2 (fig. 5), using above mentioned apparatus (fig. 7).

As a result of these tests, the mechanical behaviour is presented in the following diagrams, applied force displacement according to figure 8 ( $a$ and $b$ ), figure 9 (a and $b$ ), figure 10 ( $a$ and $b$ ) and figure 11 ( $a$ and $b$ ), below. The goal of these tests is to characterize the mechanical behaviour of the composite structures with different cellular polymer core at tensile test condition.

Therefore, it results from each corresponding diagram of the tested composite structure, the maximum tensile 


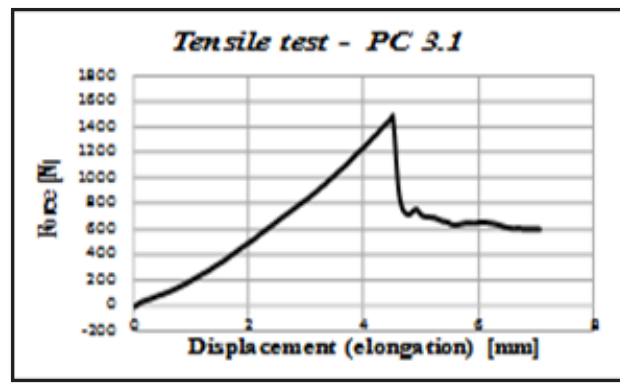

a)

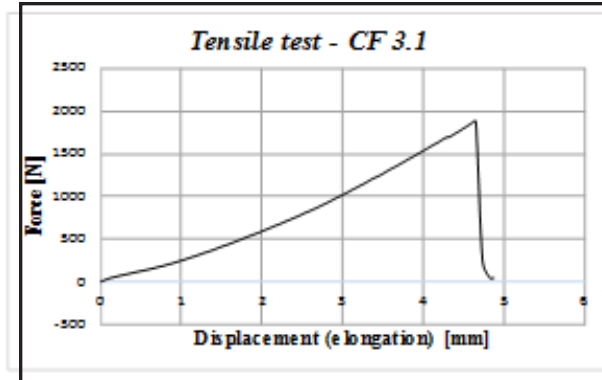

a)

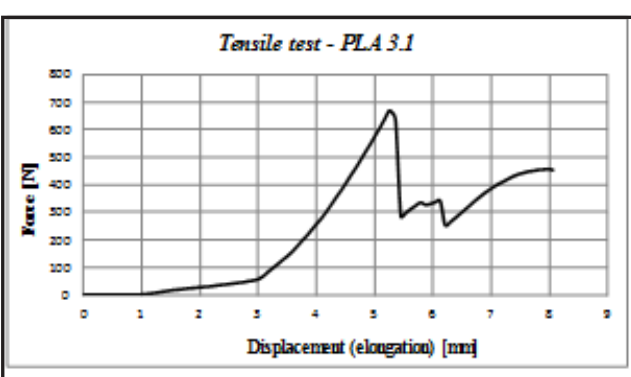

a)

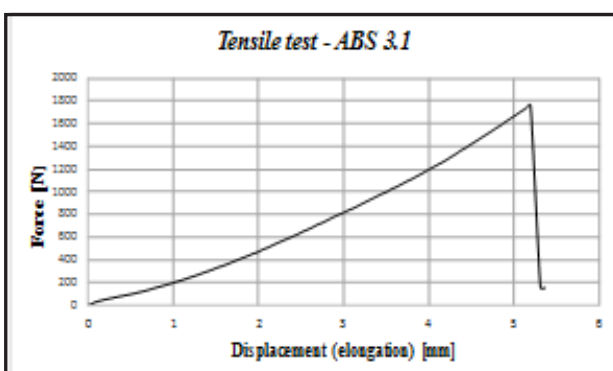

a)

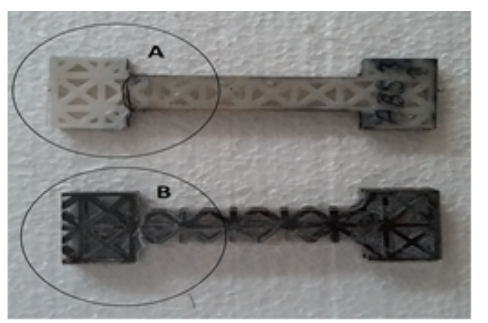

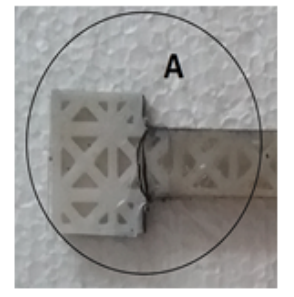

a)

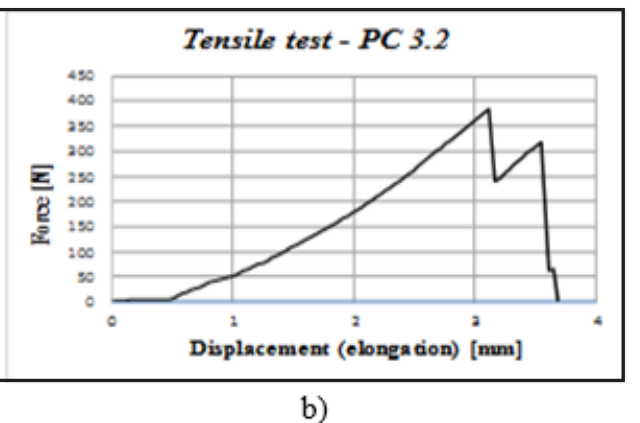

b)
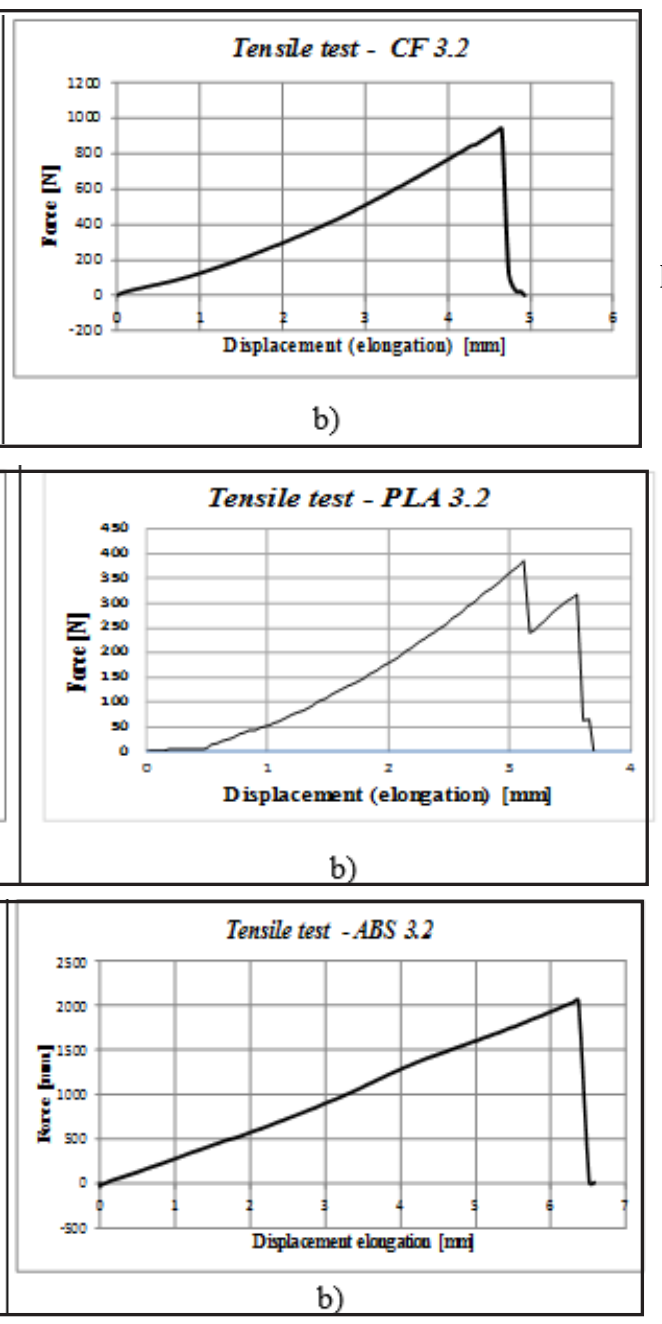

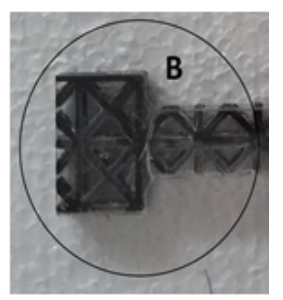

b)
Fig. 8. The applied force displacement (elongation) diagram for test-pieces having composite polymer based cellular core from polycarbonate (PC), $3 \mathrm{~mm}$ thickness:

a) PC 3.1 ; b) PC3.2.

Fig. 9. The applied force displacement (elongation) diagram for test-pieces having composite polymer based cellular core from polylactic acid with $40 \%$ carbon fiber inserts - CF, $3 \mathrm{~mm}$ thickness: a) CF3.1; b) CF3.2.

Fig. 10. The applied force displacement (elongation) diagram for test-pieces having composite polymer based cellular core from polylactic acid - PLA, $3 \mathrm{~mm}$ thickness: a) PLA3.1; b) PLA3.2

Fig. 11. The applied force displacement (elongation) diagram for test-pieces having composite polymer based cellular core from ABS, 3 mm thickness: a) ABS3.1; b) ABS3.2

force and the maximum displacement of the test-piece until reaching the breaking point. Using these characteristics, conclusions can be drawn on the tensile strength of the analysed structure to assess the optimum structure.

The assessment of the characteristic diagrams from figure 8 - figure 11 shows the following conclusions:

a) the arrangement of the test specimens with the polymer based cellular core having closed cell walls 3.1 (fig. 6) had a failure behaviour with at least $50 \%$ better than of those with open cell walls 3.2 arrangement (fig. 6). For tensile test, itcan be observed that, in case of the closed cell walls, the tendency of stress distribution along the length of the cell wall and then the failure in the intersecting cell diagonals. Also, the arrangement of the polymer based core 3.2 (fig. 6), exposes the whole cell to axial load in the intersection area with diagonals, causing a decrease in the strength of the structure (fig. 12);

b) the study of the force - displacement curve show that composite materials with polymer based cellular core made from ABS and CF have a brittle fracture behaviour, given by the brittle behaviour of the facesheets, butalso by the core material;

c) composite materials with polymer based cellular core made from PC and PLA have a ductile behaviour. In the 


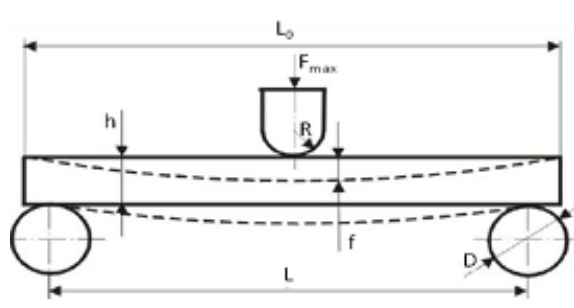

a)

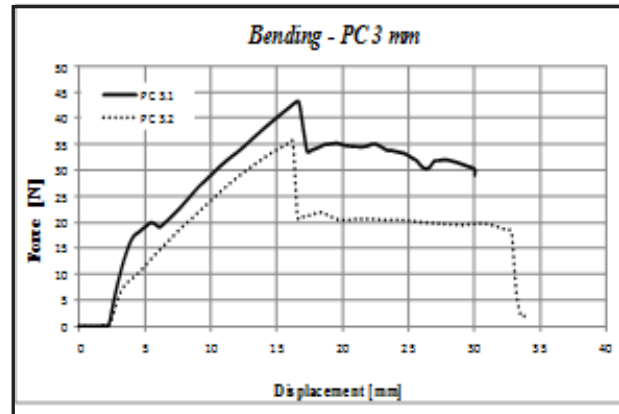

a)

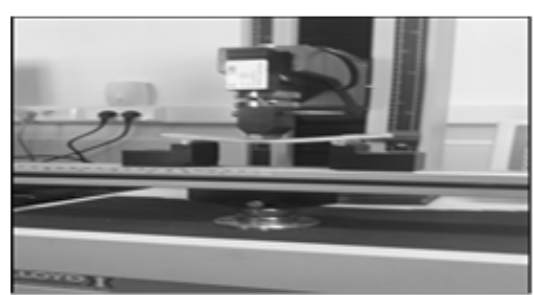

b)

Fig. 13. Bending test at 3 Points: a) Scheme of the test $\left(L=100 \mathrm{~mm}, L_{0}=150 \mathrm{~mm}\right.$,

$D=10 \mathrm{~mm}, R=10 \mathrm{~mm}, h=7.5-9.5 \mathrm{~mm}$ );

b) Testing machine - AMETEK Lloyd Instruments LS 2,5 [22]

Fig. 14. The applied force -

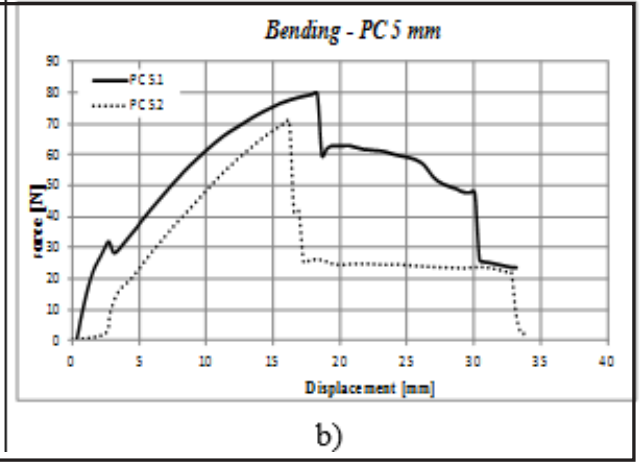
displacement diagram, for test-pieces having composite polymer based cellular core from PC: a) $3 \mathrm{~mm}$ thickness; b) $5 \mathrm{~mm}$ thickness.

Fig. 15. The applied force displacement diagram, for samples for test-pieces having composite polymer based cellular core from CF: a) $3 \mathrm{~mm}$ thickness; b) $5 \mathrm{~mm}$ thickness

Fig. 16. The applied force displacement diagram, for samples for test-pieces having composite polymer based cellular core from PLA: a) $3 \mathrm{~mm}$ thickness; b) $5 \mathrm{~mm}$ thickness.

a)

first part of the curves, a linear increase can be observed, followed by a sudden failure of the upper face, then a period of elongation of composite core up to breaking. It follows that in this case, the exterior polymer facesheets I and II (fig. 1), is the one that contributes significantly to the strength of the structure.

\section{Bending test results}

Bending tests (B) for the test specimens made of composite materials with the same core cellular polymer
Fig. 17. The applied force displacement diagram, for samples for test-pieces having composite polymer based cellular core from ABS: a) $3 \mathrm{~mm}$ thickness; b) $5 \mathrm{~mm}$ thickness

b)

Bending - $A B S 5$ mm

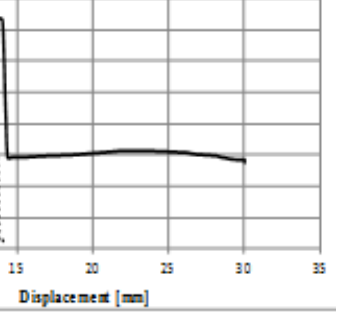

as the previous ones (PC, CF, PLA and $A B S)$, are using the same apparatus from figure 6 , above, but with the addition of some simple adaptive devices, following the 3 points bending test (fig. 13).

As a result of these tests, following the characteristic diagrams, force -maximum displacement, per figure 14 ( $a$ and $b$ ), figure 15 ( $a$ and $b$ ) figure $16(a$ and $b$ ) and figure 17 ( $a$ and $b)$, through which can be characterized the behaviour of composite structures with different cellular 
core arrangement, thickness and material in bending test condition.

The interpretation of the diagrams figure 14 - figure 17 above, highlights the following:

a) unlike the tensile test results in which the cell arrangement has a significant impact on the structure's strength, in the case of bending, the differences are much smaller (about 5-10\%);

b) cellular polymer core thickness results in an increase of the structure's strength by $25-50 \%$, respectively an increase its stiffness;

c) different profiles of force - displacement curves emphasis different constitutive materials behaviour and therefore, different modes of failure.

\section{Conclusions}

As it can be seen from above the characteristic diagrams for tensile testing (fig. 8 to fig. 11), the applied force displacement curves present a similar profile, linearity is given by the mechanical properties of the outer facesheets, while breaking is accelerated with the facesheets failure and progressive breaking of cellular polymer core which has a lower strength than the external facings. Thus, it can be seen an increase in the stiffness with thickness increase, but at the same time, the arrangement of the cell structure has a significant role over the strength of the structure, as do all materials tested with the cellular polymer core 3.1 to have an improved tensile strength in relation to cellular core, 3.2.

Similarly, in case of bending tests on the same cellular polymer core structures, the characteristic curves resulted from figure 14 - figure 17, from which the applied force maximum displacement curves highlight fair differences made by the arrangement of the cells in the polymer based core. In this case, however it is obvious the positive impact of polymer cellular core on the integrity of the structures.

Therefore, the results of tests carried out on cellular polymer core structures are of particular importance for the evaluation of the mechanical properties, with a view to the optimal of their areas of use.

Acknowledgement: This work was partially supported by the strategic grant POSDRU/159/1.5/S/137070 (2014) of the Ministry of National Education, Romania, co-financed by the European Social Fund Investing in People, within the Sectoral Operational Programme Human Resources Development 2007-2013

\section{References}

1.SYNGELLAKIS, S., Composites: Advances in Manufacture and Characterisation. Wessex, UK: Wessex Institute of Technology, UK, 2016. ISBN 978-1-78466-167-0.

2.SCHEFFLER, M., COLOMBO, P., Cellular Ceramics: Structure, Manufacturing, Properties and Applications. s.l. : John Wiley \& Sons, 2016. ISBN: 9783527313204.

3.BLACK, S., Getting To The Core Of Composite Laminates. s.I.: Revista "Composites World", Octombrie, 2013.

4. ${ }^{* * *}$ ASM International, Atlas of Stress-strain Curves, ASM International, 2002.

5.ZENKERT, D., The handbook of sandwich construction. EMAS LTD, 1997.
6.ZENKERT, D., Sandwich beam theory - an introduction, in: Ferreira, A.J .M. (Ed.), Advanced School on Sandw ich Structures, Porto, Portugal, 2008.

7.ZENKERT, D., Sandwich plate theory - an introduction, in: Ferreira, A.J .M. (Ed.), Advanced School on Sandwich Structures, Porto, Portugal, 2008.

8.ZUPAN, M., CHEN, C., FLECK, N.A., The plastic collapse and energy absorption capacity of egg-box panels, International Journal of Mechanical Sciences 45, p.851-871, 2003.

9.ADAMS, D. O., A Comparison of CEN and ASTM test methods for composite materials. Washington: U.S. Department of Transportation, Federal Aviation Administration, 2004.

10.DURBACA, A.C., Raport nr. 5, Cercetari experimentale ale compozitelor stratificate ,sandwich de tip cadru plan cu inserpe polimericã celularã, UPB, FIMM, iunie 2016.

11.PENDLETON, R. L., TUTLE, M. E., Manual of Experimental Methods for Mechanical Testing of Composites. S.l., SEM, 1989.

12.PARSONS, M. W., PASCOE, K. J., Development of a Biaxial Fatigue Testing Rig. s.l., Journal of Strain Analysis, Vol. 10, Issue 1, 1975.

13.CONSTANTIN, N., JIGA, G., HORHOIANU, N., HADAR, A., Cadru experimental pentru încercarea epruvetelor în regim de solicitare biaxialã, Bucuresti, Revista Constructia de masini, nr. 8-9, august septembrie 1995.

14.KUMAR, G.S., KUMAR, K., Surface roughness investigation and prediction models for polyjet 3D printed parts, Leiria, Portugal, High Value Manufacturing, Advanced Research in Virtual and Rapid Prototyping, Proceedings of the 6th International Conference on Advanced Research in Virtual and Rapid Prototyping, 2013.

15.GIBSON, I., ROSEN, D., STUCKER, B., Additive Manufacturing Technologies, 3D Printing, Rapid Prototyping and Direct Digital Manufacturing. s.l., Springer, 2014.

16.GUO, N., LEU, C., Additive manufacturing: technology, applications and research needs. s.l., Frontiers of Mechanical Engineering, Volume 8, Issue 3, p.215-243, 2013.

17.KRUTH, J.P., LEU, M.C., NAKAGAWA, T., Progress in Additive Manufacturing and Rapid Prototyping. s.I., CIRP Annals - Manufacturing Technology, Volume 47, Issue 2, 1998, p.525-540, 1998.

18.SMITH, R., 7 Ways 3D Printing Is Already Disrupting Global Manufacturing, Forbes, 2015, [Interactiv][Citat: 12 Mai 2016] http:// www.forbes.com/sites/ricksmith/2015/06/29/7-ways-3d-printing-isalready-disrupting-global-manufacturing/\# 1a8814d1158b.

19.ZUKAS, V., ZUKAS, J.A., An Introduction to 3D Printing. s.l., First Edition Design Pub, 2015.

20.HERRANEN, H., Design and Testing of Sandwich Structures with Different Core Materials, MATERIALS SCIENCE (MEDZIAGOTYRA), Vol. 18, No. 1, 2012, Lithuania, ISSN 1392-1320, 2012.

21. *** Airwolf 3D - Manual de utilizare imprimanta 3D, [Interactiv] [Citat: 18 Mai 2016.] http://airw olf3d.com/wp-content/uploads/2014/07/ HD2x Manual1.pdf.

22. ${ }^{* * *}$ AMETEK Lloyd Instruments. Manual de prezentare - Ma-ina de testare pentru materiale avansate LS2.5kN. [Interactiv] [Citat: 4 lunie 2016.] http://www.ametektest.com/media/ametektest/download_links/ datasinglecolumnteststandsls25datasheetenglish.pdf.

23. DURBACA, I., POPA, N., VOICU, GH., DURBACA, A.C., Theoretical and Experimental Approaches Specific to Monolayer Composite Plates Obtained from Urban and Industrial Recycled Plastic Wastes and Proteic Fibers, Mat. Plast., 52, no. 4, 2015, p. 464

Manuscript received: 3.06 .2017 